\title{
DAVID ELLERMAN
}

\section{INALIENABLE RIGHTS: A LITMUS TEST FOR LIBERAL THEORIES OF JUSTICE}

\author{
(Accepted 24 March 2010)
}

\begin{abstract}
Liberal-contractarian philosophies of justice see the unjust systems of slavery and autocracy in the past as being based on coercion-whereas the social order in modern democratic market societies is based on consent and contract. However, the 'best' case for slavery and autocracy in the past were consent-based contractarian arguments. Hence, our first task is to recover those 'forgotten' apologia for slavery and autocracy. To counter those consent-based arguments, the historical antislavery and democratic movements developed a theory of inalienable rights. Our second task is to recover that theory and to consider several other applications of the theory. Finally, the liberal theories of justice expounded by John Rawls and by Robert Nozick are briefly examined from this perspective.
\end{abstract}

\section{INTRODUCTION AND OVERVIEW}

Inalienable rights are not rights that require consent to be alienated; inalienable rights are rights that may not be alienated even with consent. If a consensual contract to alienate a certain right was for some reason inherently invalid, then the right would be inalienable. The topic of inalienable rights is bound up with contractarian theories of justice, where we might take John Rawls as a modern representative, and with (classical) liberal theories of justice, where we might take Robert Nozick as a representative (at least on the libertarian end of the spectrum). My focus is on the common foundation of consent and contracts that is shared by contractarian and liberal theories of justice.

Since liberalism and contractarianism both put an emphasis on contracts, it should be a matter of some importance to know 
if there are some contracts that ought to be considered inherently invalid and thus certain rights which are inalienable.

- The paradigm individual example to consider is a contract to sell oneself into slavery, the self-sale contract.

- The paradigm political example is a social contract of subjection, a pactum subjectionis which transferred and alienated the right of self-government to a (Hobbesian) sovereign.

- The paradigm domestic example is the old coverture marriage contract wherein the wife suspended her independent legal personality (feme sole) in favor of being a feme covert whose legal personality was subsumed under the legal person of her 'lord and baron'.

Robert Nozick was one of the few modern philosophers to explicitly consider the first two examples and to treat them within his theory. Controversially, he pointed out that the libertarian philosophy would accept both these contracts as being valid or legally permitted. He argued that a free libertarian society should validate the political alienation contract with a 'dominant protective association' playing the role of the sovereign. And the same reasoning would re-validate ${ }^{2}$ the individual version of the alienation contract:

The comparable question about an individual is whether a free system will allow him to sell himself into slavery. I believe that it would. ${ }^{3}$

Regardless of whether or not this was Nozick's considered personal judgment in 'reflective equilibrium', he did a service to philosophy by grinding out the logic of the liberal-contractar-

${ }^{1}$ Nozick (1974).

2 It would be 're-validate' since in the decade before the Civil War, six states had explicit laws 'to permit a free Negro to become a slave voluntarily' (Gray 1958, p. 527). For instance in Louisiana, legislation was passed in 1859 'which would enable free persons of color to voluntarily select masters and become slaves for life' (Sterkx 1972, p. 149).

${ }^{3}$ Nozick, Anarchy, p. 331. 
ian vision unconstrained by any inalienable rights theory. ${ }^{4}$ Few, if any, other philosophers would personally agree that these contracts should be allowed, but there is a distinct lack of theory which yields that result. ${ }^{5}$

A third paradigm example of a personal alienation contract is the old coverture marriage contract, wherein the wife contractually alienated her independent legal personality to become a sort of subperson or dependent under the 'cover' of the husband. Like the self-sale contract and political pact of subjection, the coverture marriage contract is now outlawed in modern democratic societies. But with a few exceptions, notably the work of Carole Pateman, there is little theory in the modern literature as to why such a contract (perhaps in a non-gendered form) should be considered inherently invalid.

The modern inattention to a theory of inalienability is naturally matched by a comparable neglect of the consent-based contractarian arguments made historically for slavery and for autocratic governments. Of course, there were those who defended slavery or autocracy on racial, patriarchal, or religious grounds ('Divine Right'), and liberal intellectual history tends to dote on such arguments as the only alternatives. But our focus is on the sophisticated or 'best' contractual arguments for the permissibility of slavery or autocracy even within the natural rights tradition which considered such rights as alienable. In response to those historical arguments in the alienable natural rights tradition, the democratic and anti-slavery movements developed a

${ }^{4}$ Sometimes 'inalienable rights' are defined as rights which may not be taken away, say, by the government without consent, and Nozick, of course, emphasized such rights. But those are better termed (alienable) rights as opposed to some privileges that were granted and may be rescinded by the government. Nozick had no notion of inalienable rights in the usual sense of not being alienable even with consent.

${ }^{5}$ The author's pseudonymous spoof of Nozick-Philmore (1982; reprinted with explanation in Ellerman 1995) - shows the flaws in the rather superficial arguments against the self-enslavement contract given by the few liberal authors who explicitly consider it. The point of the spoof was to encourage the retrieval of the deeper inalienability theory developed historically to defeat apologies for slavery based on implicit or explicit contracts - a retrieval that was in fact carried out in Pateman (1988). 
theory of inalienability which descends from the Reformation and Enlightenment (with some anticipation by the Stoics).

Hence, our task is largely retrieval. First, the consent-based contractarian arguments for autocracy and slavery need to be reviewed, and then the theory of inalienability that descends from the Reformation and Enlightenment needs to be recovered in a modern form. When that theory is reassembled, it becomes clear that the modern self-rental contract, ${ }^{6}$ i.e., the employment contract, would also be ruled out by the theory. This rather controversial result then provides a basis to re-evaluate modern liberalcontractarian philosophy such as the work of John Rawls and Robert Nozick. For instance, Rawls lived his whole life in an economy based on the renting (or, as it is usually called, hiring) of human beings, and yet in his writings about justice he never considered the possibility that there might be something inherently wrong with the contract to rent persons. Thus, if the inalienability argument that rules out the self-sale contract, the political pact of subjection, and the coverture marriage contract also rules out the employer-employee contract, then this would point to a major problem in Rawls' theory and indeed in modern liberal or contractarian philosophy as a whole.

\section{BRIEF HISTORY OF VOLUNTARY SLAVERY CONTRACTS}

For liberalism, the most basic frame is the question of consent versus coercion. Often slavery is seen as being coercive by definition' so there is no need to consider a voluntary selfenslavement contract. But semantics aside, from ancient times there have been defenses of slavery on contractual grounds.

In the Institutes of Justinian, Roman law provided three legal ways to become a slave:

Slaves either are born or become so. They are born so when their mother is a slave; they become so either by the law of nations, that is, by captivity, or by the civil law, as when a free person, above the age of twenty, suffers himself to be sold, that he may share the price given for him. ${ }^{7}$

\footnotetext{
6 'Since slavery was abolished, human earning power is forbidden by law to be capitalized. A man is not even free to sell himself; he must rent himself at a wage' (Samuelson 1976, p. 52) (emphasis in original).

${ }^{7}$ Institutes Lib. I, Tit. III, 4.
} 
In addition to the third means of outright contractual slavery, the other two means were also seen as having aspects of contract. A person born of a slave mother and raised using the master's food, clothing, and shelter was considered as being in a perpetual servitude contract to trade a lifetime of labor for those past and future provisions. In the alienable natural rights tradition, Samuel Pufendorf gave that contractual interpretation:

Whereas, therefore, the Master afforded such Infant Nourishment, long before his Service could be of any Use to him; and whereas all the following Services of his Life could not much exceed the Value of his Maintenance, he is not to leave his Master's Service without his Consent. But 'tis manifest, That since these Bondmen came into a State of Servitude not by any Fault of their own, there can be no Pretence that they should be otherwise dealt withal, than as if they were in the Condition of perpetual hired Servants. ${ }^{8}$

Manumission was an early repayment or cancellation of that debt. And Thomas Hobbes, for example, clearly saw a 'covenant' in this ancient practice of enslaving prisoners of war:

And this dominion is then acquired to the victor when the vanquished, to avoid the present stroke of death, covenants either in express words or by other sufficient signs of the will that, so long as his life and the liberty of his body is allowed him, the victor shall have the use thereof at his pleasure.... It is not, therefore, the victory that gives the right of dominion over the vanquished but his own covenant. ${ }^{9}$

Thus, all of the three legal means of becoming a slave in Roman law had explicit or implicit contractual interpretations.

In addition to giving a contractual interpretation to the slavery of a child born of a slave mother, Pufendorf noted that an explicit slavery contract was a lifetime version of the master-servant contract (employment contract in modern terms) where a servant could be hired for a certain time and would receive wages:

But to such a Servant as voluntarily offers himself to perpetual Servitude, the Master is obliged to allow perpetual Maintenance, and all Necessaries for this Life; it being his Duty on the other hand to give his constant Labour in all Services whereto his Master shall command him, and whatsoever he shall gain thereby, he is to deliver to him. ${ }^{10}$

\footnotetext{
${ }^{8}$ Pufendorf (2003 [1673], pp. 186-187).

${ }^{9}$ Hobbes (1958 [1651]), Bk. II, Chap. 20.

${ }^{10}$ Pufendorf, Whole Duty, p. 185.
} 
John Locke's Two Treatises of Government is a classic of liberal thought. Locke would not condone a contract that gave the master the power of life or death over the slave:

For a Man, not having the Power of his own Life, cannot, by Compact or his own Consent, enslave himself to any one, nor put himself under the Absolute, Arbitrary Power of another, to take away his Life, when he pleases. ${ }^{11}$

Locke is ruling out a voluntary version of the old Roman slavery, where the master could take the life of the slave with impunity. But once the contract was put on a more civilized footing, Locke saw no problem and nicely renamed it 'drudgery':

For, if once Compact enter between them, and make an agreement for a limited Power on the one side, and Obedience on the other, the State of War and Slavery ceases, as long as the Compact endures.... I confess, we find among the Jews, as well as other Nations, that Men did sell themselves; but, 'tis plain, this was only to Drudgery, not to Slavery. For, it is evident, the Person sold was not under an Absolute, Arbitrary, Despotical Power. ${ }^{12}$

Moreover, Locke agreed with Hobbes on the practice of enslaving the captives in a 'Just War' as a quid pro quo exchange based on the on-going consent of the captive:

Indeed having, by his fault, forfeited his own Life, by some Act that deserves Death; he, to whom he has forfeited it, may (when he has him in his Power) delay to take it, and make use of him to his own Service, and he does him no injury by it. For, whenever he finds the hardship of his Slavery out-weigh the value of his Life, 'tis in his Power, by resisting the Will of his Master, to draw on himself the Death he desires. ${ }^{13}$

Locke seemed to have justified slavery in the Carolinas by interpreting the raids into Africa as just wars and the slaves as the captives. ${ }^{14}$

William Blackstone's codification of common law was quite important in the development of English and American jurisprudence. Like Locke, Blackstone rules out slavery where 'an absolute and unlimited power is given to the master over the life

${ }^{11}$ Locke (1960 [1690]), Second Treatise, §23.

12 Ibid., Second Treatise, $\$ 24$.

13 Ibid., Second Treatise, $\$ 23$.

14 Laslett (1960), notes on §24, 325-326. 
and fortune of the slave'. Such a slave would be free 'the instant he lands in England'.

Yet, with regard to any right which the master may have lawfully acquired to the perpetual service of John or Thomas, this will remain exactly in the same state as before: for this is no more than the same state of subjection for life, which every apprentice submits to for the space of seven years, or sometimes for a longer term. ${ }^{15}$

An interesting case study in the selectiveness of liberalcontractarian intellectual history is the treatment of the proslavery writers. The proslavery position is usually presented as being based on illiberal racist or paternalistic arguments. Considerable attention is lavished on illiberal paternalistic writers such as George Fitzhugh, ${ }^{16}$ while consent-based contractarian defenders of slavery are passed over in silence. For example, Reverend Samuel Seabury gave a sophisticated liberal-contractarian defense of ante-bellum slavery in the Hobbes-Pufendorf tradition of alienable natural rights theory ${ }^{17}$ :

From all which it appears that, wherever slavery exists as a settled condition or institution of society, the bond which unites master and servant is of a moral nature; founded in right, not in might;.... Let the origin of the relation have been what it may, yet when once it can plead such prescription of time as to have received a fixed and determinate character, it must be assumed to be founded in the consent of the parties, and to be, to all intents and purposes, a compact or covenant, of the same kind with that which lies at the foundation of all human society. ${ }^{18}$

Seabury easily anticipated the retort to his classical tacitcontract argument:

"Contract!" methinks I hear them exclaim; "look at the poor fugitive from his master's service! He bound by contract! A good joke, truly." But ask these same men what binds them to society? Are they slaves to their rulers?

\footnotetext{
15 Blackstone (1959 [1765], p. 72), section on Master and Servant.

16 See, for example, Genovese (1971); Wish (1960); or Fitzhugh [1960 (1857)].

${ }^{17}$ McKitrick (1963) collects essays of fifteen pro-slavery writers but does not include a single writer who argues to allow slavery on a contractual basis such as Seabury - not to mention Grotius, Pufendorf, Locke, Blackstone and a host of others.

18 Seabury (1969 [1861], p. 144).
} 
O no! They are bound together by the COMPACT on which society is founded. Very good; but did you ever sign this compact? Did your fathers every sign it? "No; it is a tacit and implied contract."19

If modern contractarian liberals had recognized the past contractarian arguments for slavery (and autocracy), then they might be in the uncomfortable position of disagreeing with those proslavery thinkers not in principle but only in matters of fact. They might be reduced to special pleas that the implied 'social contract' has 'genuine' tacit consent, but that the implied slavery contract did not. It is no surprise that modern liberalcontractarian thinkers have just avoided this whole quandary by promulgating the consent-or-coercion framing of the slavery debates. The pro-slavery contractual arguments go down the memory hole; it's just a question of consent or coercion. And liberal-contractarian thinkers have taken a stand foursquare in favor of consent as opposed to coercion.

\section{BRIEF HISTORY OF VOLUNTARY CONTRACTS OF SUBJECTION}

It was previously noted that there were both individual and collective versions of the contract to alienate the rights of selfgovernance. The collective version was the pact of subjection, the pactum subjectionis, which alienated and transferred the people's rights of self-governance to a sovereign who then ruled in the sovereign's own name - not as a delegate, representative, or trustee of the people. By the contract of subjection, the people became subjects of the sovereign.

Here again, the intellectual history of the debate between autocracy and democracy has been reframed as a question of coercion or consent. Democracy is presented as 'government based on consent of the governed' and non-democratic governments are presented as being based on coercion. ${ }^{20}$ But there was a contractarian defense of non-democratic government from Antiquity down to Harvard's Nozick.

${ }^{19}$ Ibid., p. 153.

${ }^{20}$ For instance, John Locke took Robert Filmer's apologia for absolutism based on patriarchy as his foil rather than Hobbes' contractual theory. 
We may again start with Roman law. The sovereignty of the Roman emperor was usually seen as being founded on a contract of rulership enacted by the Roman people. The Roman jurist Ulpian gave the classic and oft-quoted statement of this view in the Institutes of Justinian:

Whatever has pleased the prince has the force of law, since the Roman people by the lex regia enacted concerning his imperium, have yielded up to him all their power and authority. ${ }^{21}$

The American constitutional scholar, Edward S. Corwin, noted the questions that arose in the Middle Ages about the nature of this pact:

During the Middle Ages the question was much debated whether the lex regia effected an absolute alienation (translatio) of the legislative power to the Emperor, or was a revocable delegation (cessio). The champions of popular sovereignty at the end of this period, like Marsiglio of Padua in his Defensor Pacis, took the latter view. ${ }^{22}$

It is precisely this question of translatio or concessio - alienation or delegation of the right of government in the contract - that is the key question, not consent versus coercion. Consent is on both sides of that alienation (translatio) versus delegation (concessio) framing of the question. The alienation version of the contract became a sophisticated tacit contract defense of non-democratic government wherever the latter existed as a settled condition. And the delegation version of the contract became the foundation for democratic theory.

The German legal thinker, Otto Gierke, was quite clear about the alienation-vs.-delegation question:

This dispute also reaches far back into the Middle Ages. It first took a strictly juristic form in the dispute... as to the legal nature of the ancient "translatio imperii" from the Roman people to the Princeps. One school explained this as a definitive and irrevocable alienation of power, the other as a mere concession of its use and exercise.... On the one hand from the people's abdication the most absolute sovereignty of the prince might be deduced,.... On the other hand the assumption of a mere "concessio imperii" led to the doctrine of popular sovereignty. ${ }^{23}$

${ }^{21}$ Institutes, Lib. I, Tit. II, 6; Quoted in Corwin (1955, p. 4).

${ }^{22}$ Corwin, Higher Law, p. 4, fn. 8.

23 Gierke (1966, pp. 93-94). 
A state of government which had been settled for many years was ex post facto legitimated by the tacit consent of the people. Thomas Aquinas expressed the canonical medieval view:

Aquinas had laid it down in his Summary of Theology that, although the consent of the people is essential in order to establish a legitimate political society, the act of instituting a ruler always involves the citizens in alienating - rather than merely delegating - their original sovereign authority. ${ }^{24}$

In about 1310, according to Gierke, 'Engelbert of Volkersdorf is the first to declare in a general way that all regna et principatus originated in a pactum subjectionis which satisfied a natural want and instinct'.

After noting that an individual could sell himself into slavery under Hebrew and Roman law, Hugo Grotius extends the possibility to the political level.

Now if an individual may do so, why may not a whole people, for the benefit of better government and more certain protection, completely transfer their sovereign rights to one or more persons, without reserving any portion to themselves? ${ }^{26}$

Thomas Hobbes made the best-known attempt to found nondemocratic government on the consent of the governed. Without an overarching power to hold people in awe, life would be a constant war of all against all. To prevent this state of chaos and strife, men should join together and voluntarily alienate and transfer the right of self-government to a person or body of persons as the sovereign. This pactum subjectionis would be a

covenant of every man with every man, in such manner as if every man should say to every man, I authorize and give up my right of governing myself to this man, or to this assembly of men, on this condition, that you give up your right to him and authorize all his actions in like manner. ${ }^{27}$

The consent-based contractarian tradition is brought fully up to date in Robert Nozick's contemporary libertarian defense of the contract to alienate one's right of self-determination to a 'dominant protective association'.

\footnotetext{
${ }^{24}$ Skinner (1978, Vol. 1, p. 62).

${ }^{25}$ Gierke (1958, p. 146).

${ }^{26}$ Grotius (1901 [1625], p. 63).

${ }^{27}$ Hobbes (1958 [1651], p. 142).
} 
In view of this history of apologetics for autocracy based on consent, the distinction between coercion and government based on the 'consent of the governed' was not the key to democratic theory. The real debate was within the sphere of consent and was between the alienation (translatio) and delegation (concessio) versions of the basic social or political constitution. Late medieval thinkers such as Marsilius of Padua and Bartolus of Saxoferrato laid some of the foundations for democratic theory in the distinction between consent that establishes a relation of delegation and trusteeship versus consent to an alienation of authority:

The theory of popular sovereignty developed by Marsiglio [Marsilius] and Bartolus was destined to play a major role in shaping the most radical version of early modern constitutionalism. Already they are prepared to argue that sovereignty lies with the people, that they only delegate and never alienate it, and thus that no legitimate ruler can ever enjoy a higher status than that of an official appointed by, and capable of being dismissed by, his own subjects. ${ }^{28}$

\section{As Marsilius put it:}

The aforesaid whole body of citizens or the weightier part thereof is the legislator regardless of whether it makes the law directly by itself or entrusts the making of it to some person or persons, who are not and cannot be the legislator in the absolute sense, but only in a relative sense and for a particular time and in accordance with the authority of the primary legislator. ${ }^{29}$

According to Bartolus, the citizens 'constitute their own princeps' so any authority held by their rulers and magistrates 'is only delegated to them (concessum est) by the sovereign body of the people'. ${ }^{30}$ To secure that distinction for democratic theory, the task was to develop arguments that there was something inherently invalid in the alienation or translatio contracts, and thus that the rights which these contracts pretended to alienate were in fact inalienable. ${ }^{31}$

\footnotetext{
${ }^{28}$ Skinner, Foundations, Vol. 1, p. 65.

${ }^{29}$ Marsilius of Padua (1980 [1324], p. 45).

${ }^{30}$ Skinner, Foundations, Vol. 1, p. 62.

31 The alienation-versus-delegation theme naturally receives more attention from intellectual historians of civic-republican bent, such as Skinner (not to mention Gierke), in contrast with those of liberal bent, e.g., Israel (2010).
} 


\section{THE INALIENABLE RIGHTS THEORY}

We have seen that the debate about slavery and autocracy was not a simple consent-versus-coercion debate. From antiquity down to the present, there were consent-based arguments for slavery and non-democratic government as being founded on certain explicit or implicit contracts. Hence, in the counterarguments of the abolitionist and democratic movements, it was not enough to criticize divine rights or the coercion of people of another race who were considered of diminished capacity. The democratic and abolitionist movements needed to counter not the worst but the 'best' arguments for slavery and autocracy. They needed to counter the arguments that slavery and autocracy could be based on explicit or implicit contracts.

The key idea in the counterargument was that in consenting to such a personal alienation contract, a person is agreeing to, in effect, take on the legal role of a non-adult, indeed, a nonperson or thing. Yet all the consent in the world would not in fact turn an adult with capacity into a minor or person of diminished capacity, not to mention, turn a person into a thing. The most the person could do was to obey the master, sovereign, or employer - and the authorities would 'count' that as fulfilling the contract. Then all the legal rights and obligations would be assigned according to the 'contract' (as if the person in fact had diminished or no capacity). But the attributes that make one a person (e.g., de facto responsible action) cannot in fact be transferred to another person. Since the person remained a de facto fully capacitated adult person with only the contractual role of a non-person or diminished person, the contract was impossible and invalid. A system of positive law that accepted such contracts would only be a fraud on an institutional scale. That, in a nutshell, is the inalienable rights theory based on the de facto nontransferability (or factual inalienability) of the attributes a person has qua person.

The 'problem' with any theory (as opposed to a catalogue of personal views) is that it may have 'legs of its own' and go further that the intended applications. The inalienability theory is a case in point since it applies as well to the self-rental contract — that is, today's employment contract — as to the self-sale 
contract or pact of subjection. One can certainly voluntarily agree to a contract to be 'employed' by an 'employer' on a long or short term basis, but one cannot in fact 'transfer' one's own actions for the long or short term. The factual inalienability of responsible human action and decision-making is independent of the duration of the contract. That factual inalienability is also independent of the compensation paid in the contract - which is why this inalienability analysis has nothing to do with exploitation theories of either the Marxian or neoclassical (i.e., paying less than the value of marginal productivity) varieties.

Where the legal system 'validates' such contracts, it must fictitiously 'count' one's inextricably co-responsible co-operation with the 'employer' as fulfilling the employment contract - unless, of course, the employer and employee commit a crime together. The servant in work then becomes the partner in crime:

All who participate in a crime with a guilty intent are liable to punishment. A master and servant who so participate in a crime are liable criminally, not because they are master and servant, but because they jointly carried out a criminal venture and are both criminous. ${ }^{32}$

When the 'venture' being 'jointly carried out' by the employer and employee is not criminous, then the facts about human responsibility do not change. But then the fiction takes over. The joint venture or partnership is transformed into the employer's sole venture. The employee is legally transformed from being a co-responsible partner to being only an input supplier sharing no legal responsibility for either the costs or the outputs of the business.

\section{BRIEF HISTORY OF THE INALIENABILITY RIGHTS ARGUMENT}

The foundation of the inalienable rights argument was the crucial difference between persons and things in an alienation contract. Where has this insight - that a person cannot in fact voluntarily alienate the attributes of being a person - erupted in

\footnotetext{
${ }^{32}$ Batt (1967, p. 612).
} 
the history of thought? The Ancients did not see this matter clearly. For Aristotle, slavery was based on 'fact'; some adults were seen as being inherently of diminished capacity if not as 'talking instruments' marked for slavery 'from the hour of their birth'. ${ }^{33}$ Treating them as slaves was no more inappropriate for Aristotle than treating a donkey as an animal-to each according to its nature.

The Stoics held the radically different view that no one was a slave by their nature; slavery was an external condition juxtaposed to the internal freedom of the soul. Chrysippus challenged Aristotle's notion that some people were slaves by nature. By virtue of their rational and social nature, Cicero saw all men as equal under the jus naturale. Sabine found in the Stoics an anticipation of the Kantian theme to treat all humans as persons rather than as things:

Even if he were a slave he would not be, as Aristotle had said, a living tool, but more nearly as Chrysippus had said, a wage-earner for life. Or, as Kant rephrased the old ideal eighteen centuries later, a man must be treated as an end and not as a means. The astonishing fact is that Chrysippus and Cicero are closer to Kant than they are to Aristotle. ${ }^{34}$

Seneca developed the idea of external bondage and internal freedom of the soul:

It is a mistake to think that slavery penetrates the entire man. The better part of him is exempt. Bodies can be assigned to masters and be at their mercy. But the mind, at any rate, is its own master, .... The body, therefore, is what fortune hands over to a master, what he buys and sells. That inner part can never come into anyone's possession. Whatever proceeds from it is free. ${ }^{35}$

In spite of the legal role of the slave as an instrument employed by another person, the mind of the slave is sui juris.

The Stoic doctrine that the inner part cannot be delivered into bondage ${ }^{36}$ re-emerged in the Reformation doctrine of liberty of conscience. Liberal thought tends to interpret the doctrine of liberty of conscience in terms of tolerance. ${ }^{37}$ But

\footnotetext{
${ }^{33}$ Aristotle, Politics, 1254a.

34 Sabine (1958, p. 165).

35 Seneca (1995), Book III, §20, p. 257.

${ }^{36}$ Davis (1966, p. 77).

${ }^{37}$ For example, Rawls (1996).
} 
there is another aspect of the doctrine that leads to the theory of inalienable rights, and this aspect gets short shrift in liberal intellectual history.

Secular authorities who try to compel belief can only secure external conformity:

Besides, the blind, wretched folk do not see how utterly hopeless and impossible a thing they are attempting. For no matter how much they fret and fume, they cannot do more than make people obey them by word or deed; the heart they cannot constrain, though they wear themselves out trying. For the proverb is true, "Thoughts are free." Why then would they constrain people to believe from the heart, when they see that it is impossible? ${ }^{38}$

Martin Luther was explicit about the de facto element; it was 'impossible' to 'constrain people to believe from the heart':

Furthermore, every man is responsible for his own faith, and he must see it for himself that he believes rightly. As little as another can go to hell or heaven for me, so little can he believe or disbelieve for me; and as little as he can open or shut heaven or hell for me, so little can he drive me to faith or unbelief. Since, then, belief or unbelief is a matter of every one's conscience, and since this is no lessening of the secular power, the latter should be content and attend to its own affairs and permit men to believe one thing or another, as they are able and willing, and constrain no one by force. ${ }^{39}$

Perhaps it was Benedict de Spinoza who first translated the doctrine of the liberty of conscience into the political notion of a right that could not be ceded 'even with consent'. In Spinoza's Theologico-Political Treatise, he spelled out the essentials of the inalienable rights argument:

However, we have shown already (Chapter XVII) that no man's mind can possibly lie wholly at the disposition of another, for no one can willingly transfer his natural right of free reason and judgment, or be compelled so to do. For this reason government which attempts to control minds is accounted tyrannical, and it is considered an abuse of sovereignty and a usurpation of the rights of subjects, to seek to prescribe what shall be accepted as true, or rejected as false, or what opinions should actuate men in their worship of God. All these questions fall within a man's natural right, which he cannot abdicate even with consent. I admit that the judgment can be biassed in many ways, and to an almost incredible degree, so that while exempt from direct external control it may be so dependent on another man's words, that it may fitly be said to be ruled by him; but although this

\footnotetext{
${ }^{38}$ Luther (1942 [1523]).

${ }^{39}$ Ibid., p. 316.
} 
influence is carried to great lengths, it has never gone so far as to invalidate the statement, that each man's understanding is his own, and that brains are as diverse as palates. ${ }^{40}$

But it was Francis Hutcheson in the Scottish Enlightenment who arrived at the same idea in the form that was to later enter the political lexicon through the American Declaration of Independence. Although intimated in earlier works, the inalienability argument is best developed in Hutcheson's influential A System of Moral Philosophy:

Our rights are either alienable, or unalienable. The former are known by these two characters jointly, that the translation of them to others can be made effectually, and that some interest of society, or individuals consistently with it, may frequently require such translations. Thus our right to our goods and labours is naturally alienable. But where either the translation cannot be made with any effect, or where no good in human life requires it, the right is unalienable, and cannot be justly claimed by any other but the person originally possessing it. ${ }^{41}$

Hutcheson contrasts de facto alienable goods where 'the translation of them to others can be made effectually' (like a shovel) with factually inalienable faculties where 'the translation cannot be made with any effect'. This was not just some outpouring of moral emotions that one should not alienate this or that basic right. Hutcheson actually set forth a theory which could have legs of its own far beyond Hutcheson's (not to mention Luther's) intent. He based the theory on what in fact could or could not be transferred or alienated from one person to another.

Hutcheson goes onto show how the 'right of private judgment' or liberty of conscience is inalienable:

Thus no man can really change his sentiments, judgments, and inward affections, at the pleasure of another; nor can it tend to any good to make him profess what is contrary to his heart. The right of private judgment is therefore unalienable. ${ }^{42}$

Hutcheson pinpoints the factual nontransferability of private decision-making power. In the case of the criminous employee,

\footnotetext{
${ }^{40}$ Spinoza (1951 [1670], p. 257).

${ }^{41}$ Hutcheson (1755, p. 261).

42 Ibid., pp. 261-262.
} 
we saw how the employee ultimately makes the decisions himself (through ratification and voluntary obedience) in spite of what is commanded by the employer. Short of coercion, an individual's faculty of judgment cannot in fact be short circuited by a secular or religious authority:

A like natural right every intelligent being has about his own opinions, speculative or practical, to judge according to the evidence that appears to him. This right appears from the very constitution of the rational mind which can assent or dissent solely according to the evidence presented, and naturally desires knowledge. The same considerations shew this right to be unalienable: it cannot be subjected to the will of another: tho' where there is a previous judgment formed concerning the superior wisdom of another, or his infallibility, the opinion of this other, to a weak mind, may become sufficient evidence. ${ }^{43}$

Democratic theory carried over this theory from the inalienability of conscience to a critique of the Hobbesian pactum subjectionis, the contract to alienate and transfer the right of self-determination as if it were a property that could be transferred from a people to a sovereign. Few have seen these connections as clearly as Staughton Lynd in his Intellectual Origins of American Radicalism. When commenting on Hutcheson's theory, Lynd noted that when 'rights were termed 'unalienable' in this sense, it did not mean that they could not be transferred without consent, but that their nature made them untransferrable'. ${ }^{44}$ The crucial link was to go from the inalienable liberty of conscience to a theory of inalienable rights:

Like the mind's quest for religious truth from which it was derived, selfdetermination was not a claim to ownership which might be both acquired and surrendered, but an inextricable aspect of the activity of being human. ${ }^{45}$

\section{Or as Ernst Cassirer put it:}

There is, at least, one right that cannot be ceded or abandoned: the right to personality...They charged the great logician [Hobbes] with a contradiction

43 Ibid., p. 295. Note how Hutcheson even echoes Spinoza in affirming inalienability even though one's judgment might seem to be 'ruled' by another.

${ }^{44}$ Lynd (1969, p. 45).

45 Ibid., pp. 56-57. 
in terms. If a man could give up his personality he would cease being a moral being. ... There is no pactum subjectionis, no act of submission by which man can give up the state of free agent and enslave himself. For by such an act of renunciation he would give up that very character which constitutes his nature and essence: he would lose his humanity. ${ }^{46}$

In the American Declaration of Independence, 'Jefferson took his division of rights into alienable and unalienable from Hutcheson, who made the distinction popular and important'. ${ }^{47}$ But the theory behind the notion of inalienable rights was lost in the transition from the Scottish Enlightenment to the slave-holding society of ante-bellum America. The phraseology of 'inalienable rights' is a staple in the American political culture, e.g., as Fourth of July rhetoric, but the original theory of inalienability has been largely ignored or forgotten. ${ }^{48}$

\section{THE COVERTURE MARRIAGE CONTRACT AS A PERSONAL ALIENATION CONTRACT}

Another historical example of this sort of institutionalized fiction was the older and now legally invalid coverture marriage contract that 'identified' the legal personality of the wife with that of the husband:

By marriage, the husband and wife are one person in law: that is, the very being or legal existence of the woman is suspended during the marriage, or at least is incorporated and consolidated into that of the husband; under whose wing, protection, and cover, she performs everything; and is therefore called in our law-French, a feme covert, and is said to be under the protection and influence of her husband, her baron, or lord; and her condition during her marriage is called her coverture. ${ }^{49}$

In the baron-femme relationship, a female was to pass from the cover of her father to the cover of her husband (with the present-day vestiges of the bride taking the husband's family name instead of the father's, and the wedding ceremony where the bride's father 'gives away' the bride to the groom). A wife

\footnotetext{
${ }^{46}$ Cassirer (1963, p. 175).

47 Wills (1979, p. 213).

${ }^{48}$ See Ellerman (1992), for more intellectual history of the inalienability argument.

49 Blackstone (1959 [1765], p. 83), section on Husband and Wife.
} 
could own property and make contracts, but only in the name of her husband. Again, obedience counted as 'fulfilling' the contract to have the wife's legal personality subsumed under and identified with that of the husband. ${ }^{50}$

The coverture marriage contract was generally outlawed in the modern democracies during the latter part of the nineteenth century in favor of a partnership version of the marriage contract, but one could imagine a modernized gender-neutral dependency contract. One adult with full capacity would voluntarily agree to become a 'dependent' of another adult, the 'guardian' or 'sponsor', in return for whatever consideration. The independent and adult legal personality of the 'dependent' would be 'suspended' in favor of the guardian. The dependent could only make contracts and hold property under the name of the guardian. Obedience by the adult dependent to the guardian would count as 'fulfilling' this contract and the legal rights would be allocated accordingly (e.g., all property belonging to the guardian).

The gender-specific aspect of the historical coverture contract was not the basic problem. The hypothetical modernized gender-neutral version of the coverture contract would be invalid for the same reasons as the original coverture contract, the selfsale contract, or the employment contract. The adult 'dependent' remains a de facto adult, the law would accept obedience to the guardian as 'fulfilling' the contract, and then the legal

${ }^{50}$ In Carole Pateman's analysis of this sort of a 'sexual contract' in a more general setting, she pointed out the connection to the employment contract and the de facto inalienability of labor. 'The contractarian argument is unassailable all the time it is accepted that abilities can 'acquire' an external relation to an individual, and can be treated as if they were property. To treat abilities in this manner is also implicitly to accept that the 'exchange' between employer and worker is like any other exchange of material property. ... The answer to the question of how property in the person can be contracted out is that no such procedure is possible. Labour power, capacities or services, cannot be separated from the person of the worker like pieces of property'. Pateman, Sexual Contract, pp. 147-150. 
rights would be assigned accordingly as if the 'dependent' was actually a non-adult. ${ }^{51}$

In spite of the abundance of legal precedent in the historical alienation contracts such as the self-sale contract, the pactum subjectionis, and the coverture marriage contract, today's employment contract, and even some hypothetical alienation contracts (the 'dependency contract'), legal theory has yet to focus on the general notion of an alienation contract applied to persons. All these personal alienation contracts have the same scheme. An adult person with full capacity voluntarily agrees for whatever reason and in return for whatever consideration to accepting a lesser legal role. But they do not in fact alienate their capacity as a person in order to fulfill that diminished legal role. Instead, the law accepts their (non-criminous) obedience to the master as 'fulfilling' the contract. Then the rights and obligations follow the legal role (e.g., the slave of a master, the subject of a sovereign, the femme covert of her baron, the employee of the employer, and so forth) - as if the person were not in fact a person of full capacity. The whole scheme amounts to a fiction and fraud on an institutional scale that nonetheless parades upon the historical stage as a liberal institution based on consent.

\section{RENTING PEOPLE: LITMUS TEST FOR LIBERAL- CONTRACTARIAN THEORIES OF JUSTICE}

Suppose a philosopher lived his or her whole life in a society with the economy based on some people owning other people, and where the ownership was based on a contractual relationship. Suppose the philosopher wrote extensively about justice but never raised the possibility that there might be something inherently unjust and wrong in a contractual rela-

${ }^{51}$ Many modern feminist thinkers understand well the fiction and fraud involved in the old coverture contract where the husband had all the external legal rights and obligations for the 'one person in law'. However, with the exception of Carole Pateman and perhaps a few others, there seems to be little recognition of the same type of fiction and fraud involved in the employment contract where the employer takes all the legal ownership of the produced products and carries all the legal liabilities for the de facto jointly responsible activities of the people working in the enterprise. 
tionship wherein some people owned others. Regardless of what marvelous subtleties there might be in the philosopher's theory of justice, one might consider it lacking in a rather fundamental way. It would fail a rather simple litmus test. The failure to even raise the question about the ownership of other people would condemn the theory of justice as a sophisticated apologia-by-omission for the status quo.

My contention is that we are now in exactly this situation, but with 'renting other people' substituted for 'owning other people' as the litmus test. Today, any contract resembling a selfsale contract (or an upfront paid) lifetime labor contract would not be recognized as valid by the legal authorities. But the selfrental or employer-employee contract is the basis of the current economic system and is accepted by liberal-contractarian philosophers of justice as a matter of course without comment. ${ }^{52}$

The application of the inalienability theory to the employment contract does not require any deep technical knowledge of economics or the law. For instance, in the critique of the social contract of subjection by early democratic theory, the key distinction was between a contract to alienate (translatio) the right of self-government to a sovereign and a contract of delegation, trusteeship (concessio), or representation. Did the governor rule in his own name or only as the representative of the governed?

It takes no esoteric knowledge to understand that the employer-employee contract is a contract of alienation, not delegation. The employer is not the representative, trustee, or delegate of the employees. The employer manages in his or her own name and interests, not in the name or interests of those managed:

The manager in industry is not like the Minister in politics: he is not chosen by or responsible to the workers in the industry, but chosen by and responsible to partners and directors or some other autocratic authority. Instead of the manager being the Minister or servant and the men the ultimate masters, the men are the servants and the manager and the external

\footnotetext{
52 Of course, philosophers and any social commentators in general may complain about abusive employers, exploitative wages, or dangerous working conditions. But, as with slavery, the focus of analysis is properly on the system itself, not just on abuses of the system by various masters or employers.
} 
power behind him the master. Thus, while our governmental organisation is democratic in theory, ... our industrial organisation is built upon a different basis. $^{53}$

Hence, if the inalienability critique of the traditional contracts of political subjection was known and understood, then it would be an easy next step to see that it applied to the basis of our present day economy, the employment contract.

Another aspect of the theory is the inalienability of human decision-making and responsibility that Hutcheson derived from Luther in the doctrine of the liberty of conscience. But the point about human nature is not restricted to religious decisions. Deciding to obey a master's command to do $\mathrm{X}$ is only another way to decide to do $\mathrm{X}$, and the servant or employee inextricably shares in the de facto human responsibility with the master or employer for the results. Philosophers and lay people understand this quite well in the case of the hired criminal, and yet no one seriously argues that employees morph into actual instruments (rather than co-responsible persons) when their actions are legal. Thus, if the inalienability theory that descends from the Reformation were known and understood today, then it would again be an easy next step to see that it applied to the basis of our present day economy.

\section{RAWLS' THEORY OF JUSTICE}

John Rawls' Theory of Justice is generally recognized as giving the most sophisticated modern development of a liberal-contractarian theory of justice. Rawls' Harvard colleague, Robert Nozick, had a theory that explicitly accepted the voluntary slavery contract and the political pact of subjection. Although Rawls' personal views were undoubtedly against such contracts, did he have any theory that would rule out those contracts that have already been outlawed?

It was previously noted how the doctrine of the liberty of conscience was connected to the notion of inalienability with Spinoza and Hutcheson being two of the pivotal figures to explicitly make the connection as they introduced the notion of

${ }^{53}$ Zimmern (1918, p. 263). 
inalienable rights. The liberty of conscience is a central theme in Rawls' Political Liberalism, ${ }^{54}$ but the connection to inalienability is a bridge that Rawls did not cross. Rawls' treatment of inalienability is in a brief aside about the inalienability of all the basic liberties, ${ }^{55}$ where he makes an old and rather standard argument about inalienability. Like many earlier thinkers in the broadly liberal tradition, he argues against an extreme case of alienating all the basic liberties. But once the alienation becomes qualified and restricted then it is accepted.

We have already seen this same pattern of argument in Locke and Blackstone, who with great moral flourish condemned a contract to enter into an extreme form of slavery (like the Roman slavery where the master could take the slave's life). But once the contract becomes civilized and limited, then it is accepted and appropriately renamed ('drudgery' in the case of Locke and 'perpetual service' in the case of Blackstone).

Montesquieu also used this pattern of argument: 'To sell one's freedom is so repugnant to all reason as can scarcely be supposed in any man. If liberty may be rated with respect to the buyer, it is beyond all price to the seller'. ${ }^{56}$ Rawls paraphrases this argument from Montesquieu and goes onto argue that in the original position, the 'grounds upon which the parties are moved to guarantee these liberties, together with the constraints of the reasonable, explain why the basic liberties are, so to speak, beyond all price to persons so conceived'. ${ }^{57}$

Now in the passage paraphrased by Rawls, Montesquieu adds the footnote: 'I mean slavery in a strict sense, as it formerly existed among the Romans, and exists at present in our colonies'. ${ }^{58}$ As with Locke and Blackstone, Montesquieu goes

54 'Thus, the historical origin of political liberalism (and of liberalism more generally) is the Reformation and its aftermath, with the long controversies over religious toleration in the sixteenth and seventeenth centuries. Something like the modern understanding of liberty of conscience and freedom of thought began then'. (Rawls, Political Liberalism, xxvi; see also Lecture VIII) These are precisely the themes underlying Spinoza's and Hutcheson's notion of inalienability.

55 Ibid., pp. 365-367.

${ }^{56}$ Montesquieu (1912 [1748]), Vol. I, Bk. XV, Chap. II, p. 284.

57 Rawls, Political Liberalism, p. 366.

${ }^{58}$ Montesquieu, Spirit, Vol. I, Bk. XV, Chap. II, p. 284, fn. 1. 
on to note that this would not exclude a civilized or 'mild' form of the contract:

This is the true and rational origin of that mild law of slavery which obtains in some countries; and mild it ought to be, as founded on the free choice a man makes of a master, for his own benefit; which forms a mutual convention between two parties. ${ }^{59}$

And Rawls goes onto note:

This explanation of why the basic liberties are inalienable does not exclude the possibility that even in a well-ordered society some citizens may want to circumscribe or alienate one or more of their basic liberties. ...

Unless these possibilities affect the agreement of the parties in the original position (and I hold that they do not), they are irrelevant to the inalienability of the basic liberties. ${ }^{60}$

Moreover, the extreme case argument for inalienability had little relevance in the historical debates. ${ }^{61}$ The proslavery writers were quick to point out the laws protecting slaves on the ante-bellum law books and Hobbes excluded the alienation of the right to life from his pactum subjectionis (since the whole idea was to better protect life by stopping the war of all against all).

Like most modern liberal-contractarian philosophers of justice, Rawls not only fails the litmus test of ruling out the renting of people; he does not even raise the question as a topic for a Theory of Justice - which leaves that theory as a sophisticated apologia-by-omission for a society based on the human rental relationship.

But there is also an easier historical litmus test: does the theory rule out a civilized non-discriminatory version of the older personal alienation contracts, e.g., the self-sale contract, the political pact of subjection, and the coverture contract? Since all these contracts have been abolished in modern democratic societies, it would seem that a theory of justice should, at a bare minimum, be able to give a direct and coherent account about why these contracts should be invalid in spite of

59 Ibid., Vol. I, Bk. XV, Chap. V, p. 287.

${ }^{60}$ Rawls, Political Liberalism, pp. 366-367 and fn. 82.

${ }^{61}$ Other superficial arguments against slavery contracts or political pacts of subjection were treated in Philmore, Libertarian Case for Slavery. 
consent, and why the underlying rights are inalienable. This is not a question about Rawls' personal views but about whether his theory of justice ruled out these contracts.

There is something of a continuum between the self-rental contract and a civilized form of the self-sale or lifetime labor contract. Rawls' theory of justice accepted the self-rental contract completely as a matter of course, so it is hard to see how the theory could suddenly generate a bright line constraint to rule out the longer version of the master-servant contract. In ante-bellum American law, the self-sale contract was formulated in racial terms which would violate Rawls' veil of ignorance. But a limited race-neutral contract, e.g., the self-sale contract envisioned in Nozick's 'free system', would not violate that nondiscrimination condition.

Similar remarks apply to the traditional coverture marriage contract since the contract would violate the fairness condition built into the veil of ignorance. 'The same equality of the Declaration of Independence which Lincoln invoked to condemn slavery can be invoked to condemn the inequality and oppression of women'. ${ }^{62}$ But a modernized gender-neutral dependency or guardianship contract would be allowed by Rawls' theory just as the modernized master-servant contract is allowed. The discriminatory nature of the historical contracts was not the basic problem; it was the fact that the contracts put a fully capacitated person, female or male, Black or White, into the legal position of non-person or a person of impaired capacity. Hence the non-discriminatory implications of Rawls' veil of ignorance do not suffice to rule out these alienation contracts.

Similar remarks could also be applied to the political pact of subjection, the contract for the alienation of self-governance rights. Some traditional views of the hierarchy embodied in an autocracy saw most people "born with saddles on their back" with "a favored few booted and spurred, ready to ride them"63 and such views might have the contractarian gloss of an implicit contract of subjection vouchsafed by the prescription of time.

\footnotetext{
${ }^{62}$ Rawls, Political Liberalism, p. xxxi.

63 Jefferson (1904-1905, p. 225).
} 
But such hierarchical classifications would violate Rawls' veil of ignorance. However, a classless modernized self-governancealienation contract, such as Nozick's contract with a 'dominant protective association', would not be ruled out by Rawls' theory just as the theory does not rule out the workplace self-governance-alienation contract, i.e., the employment contract.

The contractarian approach is quite important in the history of philosophy since it provided the 'best' apologies for personal, political, and domestic subjection (as represented by the three implicit or explicit contracts). ${ }^{64}$ Since those three contracts are already outlawed in the modern democracies, it would seem to be a reasonable litmus test for any theory of justice set forth today that it provide a plausible counter-theory to refute those 'best' contractarian arguments. Such a theory of inalienable rights was indeed hammered out in the democratic and abolitionist movements but that theory did not survive in Rawls' work in spite of the direct connection with the liberty of conscience.

Rawls lived his whole life in an economic system where employees are 'not counted as sources of claims' on the products they produce and are "not counted as capable of having ...obligations ${ }^{65}$ to meet the costs they incur in production, and where other persons, the employers, 'control and own the product of their labor'. ${ }^{66}$ Yet in his considerable writings about justice, Rawls never raised the question of a potential justice problem inherent in the whole system of renting human beings.

The alternative form of a private property market economy after the abolition of the employment relation would have all firms reconstituted as democratic organizations with the people

${ }^{64}$ Rawls was well aware of that tradition from the history given in Philmore, Libertarian Case for Slavery (personal communication).

65 Rawls, Political Liberalism, p. 33.

66 Ibid., p. 122. The given quotes are from Rawls' description of slavery but the specific aspects quoted also apply to the system where workers are rented, hired, or employed rather than owned by an employer or master. Those aspects of the legal structure of a productive enterprise do not depend on the duration of the labor contracts, i.e., on whether the workers are hired or owned by the masters. For instance, the masters or employers 'control and own the product' of the servant's or employee's labor regardless of the duration of the hiring contract. 
working in the firm as its legal members. ${ }^{67}$ Since Rawls did not explicitly consider the inalienability analysis of the employment contract, the contract which also functions as the workplace pactum subjectionis, the 'Theory [of Justice] leaves aside for the most part the question of the claims of democracy in the firm and the workplace.... 68

\section{CONCLUSIONS}

Our overall purpose was the examination of liberal-contractarian philosophies of justice - with John Rawls and Robert Nozick as modern examples - from the viewpoint of the theory of inalienability that descends from the Reformation and Enlightenment (with some anticipation by the Stoics). Perhaps the biggest surprise in the recovery of inalienable rights theory is that it clearly applies to the contract for the renting of persons, today's employment contract. Since the employment contract is the basis for our present economic system, it should perhaps not be a surprise that the inalienability theory has been neglected by modern economists, legal theorists, and philosophers.

As each of the three historical contracts of subjection (personal, political, and sexual) were outlawed as a result of the efforts of the anti-slavery, democratic, and feminist movements, liberal-contractarian philosophy recasts each of the historical debates into a discourse of coercion versus consent. ${ }^{69}$ The past institutions of subjection are then seen as being coercive by definition and are supposedly ruled out on those grounds. Hence, there is no need to consider any potentially troublesome theory about certain voluntary contracts being inherently invalid and certain rights being inherently inalienable even with consent.

${ }^{67}$ See Ellerman (1990).

${ }^{68}$ Rawls, Political Liberalism, p. xxx.

69 And Marxism, as the preferred foil for liberalism, obligingly accepts the bogus framing and counterargues that wage labor is 'really' involuntary. 


\section{OPEN ACCESS}

This article is distributed under the terms of the Creative Commons Attribution Noncommercial License which permits any noncommercial use, distribution, and reproduction in any medium, provided the original author(s) and source are credited.

\section{REFERENCES}

Aristotle, The Politics of Aristotle (Oxford: Oxford University Press, 1958).

Batt, F., The Law of Master and Servant (London: Pitman, 1967).

Blackstone, W., Ehrlich's Blackstone, J. W. Ehrlich (ed.) (New York: Capricorn Books, 1959 [1765]).

Cassirer, E., The Myth of the State (New Haven: Yale University Press, 1963).

Corwin, E. S., The 'Higher Law' Background of American Constitutional Law (Ithaca: Cornell University Press, 1955).

Davis, D. B., The Problem of Slavery in Western Culture (Ithaca: Cornell University Press, 1966).

Ellerman, D., The Democratic Worker-Owned Firm (London: Unwin-Hyman, 1990).

Ellerman, D., Intellectual Trespassing as a Way of Life: Essays in Philosophy, Economics, and Mathematics (Lanham, MD: Rowman \& Littlefield, 1995).

Ellerman, D., Property \& Contract in Economics: The Case for Economic Democracy (Cambridge, MA: Blackwell, 1992). Downloadable from: www.ellerman.org.

Fitzhugh, G., Cannibals All! or, Slaves Without Masters (Cambridge: Harvard University Press, 1960 [1857]).

Genovese, E., The World the Slaveholders Made (New York: Vintage Books, 1971).

Gierke, O., Political Theories of the Middle Age, F. W. Maitland (trans.) (Boston: Beacon Press, 1958).

Gierke, O., The Development of Political Theory, B. Freyd (trans.) (New York: Howard Fertig, 1966).

Gray, L. C., History of Agriculture in the Southern United States to 1860 (Gloucester: Peter Smith, 1958).

Grotius, H., The Rights of War and Peace, A. C. Campbell (trans.) (Washington: M. Walter Dunne, 1901 [1625]).

Hobbes, T., Leviathan (Indianapolis: Bobbs-Merrill, 1958 [1651]).

Hutcheson, F., A System of Moral Philosophy (London, 1755).

Israel, J., A Revolution of the Mind: Radical Enlightenment and the Intellectual Origins of Modern Democracy (Princeton: Princeton University Press, 2010).

Jefferson, T., The Works of Thomas Jefferson in Twelve Volumes. Vol. 12. Correspondence and Papers: 1816-26, P. L. Ford (ed.). Federal Edition (New York: G.P. Putnam's Sons, 1904 1905). Available at: http://oll.libertyfund.org/EBooks/Jefferson_0054.12.pdf.

Justinian, The Institutes of Justinian, T. C. Sandars (trans.) (London: Longmans, Green, and Co, 1948).

Laslett, P., Introduction with Notes. in Laslett P (Ed.), John Locke: Two Treatises of Government, (New York: New American Library, 1960).

Locke, J., Two Treatises of Government, P. Laslett (ed.) (New York: New American Library, 1960 [1690]).

Luther, M., Concerning Secular Authority. in Coker FW (eds.), Readings in Political Philosophy, (New York: Macmillan, 1942) pp. 306-329.

Lynd, S., Intellectual Origins of American Radicalism (New York: Vintage Books, 1969).

Marsilius of Padua, Defensor Pacis, A. Gewirth (trans.) (Toronto: University of Toronto Press, 1980 [1324]).

McKitrick E. (Eds, Slavery Defended: The Views of the Old South (Englewood Cliffs, NJ: Prentice-Hall, 1963). 
Montesquieu, The Spirit of the Laws, T. Nugent (trans.) (New York: Appleton, 1912 [1748]).

Nozick, R., Anarchy, State, and Utopia (New York: Basic Books, 1974).

Pateman, C., The Sexual Contract (Stanford: Stanford University Press, 1988).

Philmore, J. [pseudonym for David Ellerman], 'The Libertarian Case for Slavery: A Note on Nozick', Philosophical Forum XIV(Fall): (1982), 43-58.

Pufendorf, S., The Whole Duty of Man, According to the Law of Nature (Indianapolis: Liberty Fund, 2003 [1673]).

Rawls, J., A Theory of Justice (Cambridge: Harvard University Press, 1971).

Rawls, J., Political Liberalism (New York: Columbia University Press, 1996).

Sabine, G. H., A History of Political Theory (New York: Henry Holt and Company, 1958).

Samuelson, P. A., Economics (10th ed.). (New York: McGraw-Hill, 1976).

Seabury, S., American Slavery Justified by the Law of Nature (Miami: Mnemosyne Publishing Company, 1969 [1861]).

Seneca, , On Favours (De Beneficiis). in Cooper JM, and Procope JF (eds.), Moral and Political Essays, (New York: Cambridge University Press, 1995) pp. 183-308.

Skinner, Q. The foundations of modern political thought, 2 Vols. (Cambridge: Cambridge University Press, 1978).

Spinoza, B. Theologico-Political Treatise, R. H. M. Elwes (trans.) (New York: Dover Publications, 1951 [Orig. 1670]).

Sterkx, H. E., The Free Negro in Ante-Bellum Louisiana (Cranbury, NJ: Associated University Presses, 1972).

Wills, G., Inventing America (New York: Vintage Books, 1979).

Wish H. (Eds, Ante-bellum (New York: Capricorn Books, 1960).

Zimmern, A. E., Nationality \& Government (London: Chatto \& Windus, 1918).

Department of Philosophy,

University of California at Riverside,

4044 Mt. Vernon Ave., Riverside,

CA 92507, USA

E-mail: david@ellerman.org 